\title{
Sperm sexing technology - new directions in medicine
}

\section{Tehnologia sexării materialului seminal - o nouă direcție în medicină}

\author{
Laura Pindaru $^{1 *}$, Iulia Maria Balaci ${ }^{1}$, Ioan Ștefan Groza ${ }^{2}$ \\ 1. USAMV Cluj-Napoca, Romania; 2. USAMV Cluj-Napoca Veterinary Medicine, Romania
}

Received: $8^{\text {th }}$ October 2015; Accepted: $6^{\text {th }}$ February 2016; Published: $12^{\text {th }}$ March 2016

\section{Introduction}

The advances made over the past few decades in molecular biology, biophysics, and computer science, as well as the innovative approaches of scientists, have led to the achievement of certain practical breakthroughs in a number of branches of medicine. Veterinary medicine in general - and reproductive biotechnologies in particular - are among the fields in which these endeavours have led to truly spectacular results (1).

Reproductive biotechnologies are a set of methods, procedures or operations whose main purpose is to maximize genetic potential and to obtain more offspring, under optimal conditions, beyond the limits characteristic for the specie. Among the latest-generation biotechnologies which have brought a considerable contribution to the field of reproduction are a number of assisted reproductive technologies (ART), such as: in vitro fertilization (IVF), intravaginal culture of oocytes (INVO), intracytoplasmic sperm injection (ICSI), transgenesis, embryo sexing, and sperm sexing technology $(2,3)$.
Sperm cells sexing, namely the possibility to preselect the sex of offspring prior to conception, has been, for a very long time, a major objective of reproductive biotechnologies, despite the fact that this goal involves controlling a situation which is normally left exclusively to chance (4).

The preselection of the sex of offspring prior to conception has aroused great interest since ancient times. The first attempts to control and determine the sex of the offspring were described by certain philosophers of ancient Greece. Democritus of Abdera (approx. 460-360 BC) believed that male offspring originated in the right testicle and female offspring in the left testicle (1). Moreover, it was believed that male foetuses developed more frequently in the right uterine horn, while the female foetuses - in the left uterine horn. According to this assumption, in the case of both the human and animal species, in order to obtain offspring of the desired sex, one of the testicles would have to be removed (5).

The first description of semen or "sperma" was made by Hippocrates from Kos (c.460-c.377 BC) (5), who claimed that "sperma" plays a key

*Corresponding author: Laura Pindaru Parlapan, USAMV Cluj-Napoca, Cluj-Napoca, Romania, e-mail: pindarulaura@yahoo.com 
role in the development of the product of conception. Strong "sperma" produces male descendants, while weak "sperma" - female descendants. However, all these hypotheses were based on an empirical tradition, without any scientific research basis to certify their validity (6).

Even though Anton van Leeuwenhoek, in 1677, described the spermatozoon for the first time using a simple microscope and Michael Frederick Guyer, in 1910, gave the first accounts regarding the microscopic identification of sex chromosomes in mammals, the actual scientific approaches referring to preselection of the sex of offspring prior to conception were undertaken only in the twentieth century (7).

\section{The benefits of using sexed semen}

There are multiple benefits to using sexed semen in Romania, and they have generated a high interest in both human and veterinary medicine.

Currently, there are over 10.000 known diseases that are genetically determined or conditioned and which affect the human population, of which 370 are sex-linked. Haemophilia, Duchenne and Becker muscular dystrophies, G6PD deficiency, the Lesch-Nyhan syndrome, and agammaglobulinemia are just some of the most serious diseases caused by different genes located on the X chromosome and which generally occur only in male children. Thus, in order to avoid such situations, in the case of families with a history of sex-linked diseases, the preselection of the child's sex prior to conception would be the only viable solution (8).

The application of this technique in animals also raises great interest, both from scientific as well as economic point of view (9). Thus, the acceleration of reproduction management, the optimization of the biological and economic output at farm level and the improvement of genetic background are just some of the advantages that this technology could provide for live- stock - cattle - (10), swine - $(11,12)$, sheep and goat farms (13).

The most relevant example is cattle farms, where in the case of dairy breeds the farmers prefer female offspring (10) as compared to beef breeds, where male offspring are preferred. Thus, at an approximately equal rate of male and female new-borns, as in the case of artificial insemination with non-sexed semen, half the offspring belong to an unwanted sex category, raising and then selling the cattle in question to slaughterhouses being basically unprofitable.

Thus, the spread of artificial insemination with sexed semen brings about great advantages for both farm categories (10). It is estimated that by using these technologies, bovine meat production can reach a point where it can compete with chicken meat, both in terms of its nutritional qualities and its low production costs. A reduction of cost of acquiring breeding stock as well as its rapid increase could be achieved by a preferential use of female sexed semen. The fact that female offspring weigh about 2 kilos less at birth than male offspring would significantly reduce the frequency of dystocia in this specie (14).

Considering the above, using sexed semen would also allow a substantial reduction in terms of space, fodder, and auxiliary farm staff and, implicitly, in production costs.

The use of sexed semen also raises a great interest in the case of animals destined for elite sports, such as horses, dogs, and even camels, as well as animals used for hunting. In both cases, male offspring are preferred (15).

Also, choosing the sex of offspring would be a rather important tool both in the case of reproduction management in zoos, by manipulating the gender ratio and avoiding high levels of endogamy, as well as in the case of conservation and rescue programs for endangered species. For instance, the European bison and the 
marbled polecat currently number less than 50 specimens (16).

\section{Sex determination}

According to the systematization made by David Faber, sex determination can be performed at 3 different levels (Table. 1): at pre-conception, by measuring the DNA content of male gametes; pre-implantation, by embryo biopsy followed by PCR or FISH technique; and lastly, post-implantation, by subjecting the foetuses to ultrasound or karyotyping (3).

The scientific literature contains numerous data concerning the attempts made to preselect the sex of offspring prior to conception; however, convincing proof in this respect came out only in the past few years (17).

Although physical, biochemical, and immunological differences between X- and Y-chromosome-bearing spermatozoa have been suggested, and though it has been attempted to develop several separation techniques, based on the swimming velocity of the spermatozoa, on the electric charge of the surface of the spermatozoa membrane, and on the immunological structure, no separate and viable sexed spermatozoa sub-populations have been achieved to date in a consistent manner (18).

The only effective method known at this point refers to the difference in DNA content in the case of the two spermatozoa populations (19).

According to Jafar, a sexing technique must fulfil three fundamental prerequisites in order to be considered efficient (20):
- the purity of the separated X/Y spermatozoa should be as high as possible;

- the technique used should not affect the "in vitro" or "in vivo" fertilization capacity of the sexed spermatozoa;

- it should allow for viable embryos/offspring of the desired gender to be obtained.

In order to fulfil the latter two prerequisites, it is necessary to combine sexing technology with artificial insemination, "in vitro" fertilization and/or embryo transfer (21).

The preselection of offspring sex before implantation requires embryo biopsy (22). The technique is invasive and consists in the collection of one or more cells (blastomeres) from the internal mass of the embryos, in order to perform certain cytogenetic (karyotyping) or molecular biology tests (PCR and FISH) (23).

Sex identification in offsprings after implantation can be performed only by ultrasound and/ or karyotyping.

Ultrasonography is a non-invasive method consisting in an ultrasound examination by which the migration direction of the genital tubercle is identified. This can be carried out in the case of a wide range of monotocous species, while in the case of polytocous species it is not at all relevant (24).

Karyotyping is an invasive method that involves performing an amniocentesis, in which cells are collected from the amniotic fluid, or a biopsy of the chorionic villi and drawing the individual genetic map. It is a costly technique

Table 1. Different levels of sex-preselection

\begin{tabular}{ccc}
\hline Moment of sex establishment & Biological material & Sexing method \\
\hline PRE-CONCEPTION & Spermatozoa & Measurement of DNA content \\
\hline PRE-IMPLANTATION & Embryos & Biopsy* followed by PCR or FISH \\
\hline POST-IMPLANTATION & Fetuses & $\begin{array}{c}\text { Ultrasonography } * * \\
\text { Karyotyping * }\end{array}$ \\
\hline
\end{tabular}

* - invasive method

** - non-invasive method 
used mainly for humans, especially to detect numerical or structural chromosomal anomalies, and to a lesser extent to establish the gender (25).

\section{Separation of spermatozoa based on DNA con- tent}

The first hypothesis regarding the existence of a difference between the $\mathrm{X}$ and the $\mathrm{Y}$ chromosome was issued by the Lawrence Livermore National Laboratory during a study on the effects of radiation on human health. Mouse semen was used in order to identify any possible DNA damage, but due to the flattened shape of the sperm head, the initial studies on DNA stability were not interpretable (26).

In 1970, Friedrich Otto reports that the measurement of DNA content can be accurately performed by the "coaxial measurement" of the sperm head, using a system developed by Partec GmbH (Münster, Germany). This system (Ortho Impulse Cytophotometer, ICP-22) was then used for analysing bull semen; however, the accurate measurement of the DNA content of X and Y-gonosome-bearing spermatozoa became possible only with the development and emergence on the market of flow cytometers. The first report of this technique was made by Moruzzi, in 1979, according to whom, between the total length of the $\mathrm{X}$ and $\mathrm{Y}$ chromosomes in mammals there is a difference of about $4.2 \%$ (27).

The examination of DNA content using flow cytometry in the two spermatozoa sub-populations showed a quantitative difference in the DNA of X and Y-gonosome-bearing spermatozoa, ranging between $2.3 \%$ in opossums (28), $9 \%$ in Microtus Oregoni (29), and only $2.8 \%$ in humans. For commercial species, these values vary between $3.6 \%$ in boars, $3.7 \%$ in stalions, $3.8 \%$ in bulls, and $4.2 \%$ in rams (30).

\section{Sperm Sorting Technique}

The separation Technology involves three stages:
- preparation and marking of samples;

- sample analysis and highlighting of the two sub-populations;

- separation and collection of the sorted sperm cells.

The preparation and marking of the sample involves the dilution and marking of the semen with dyes specific to nucleic acids. At first, the 4',6-diamidino-2-phenylindole fluorescent dyeing system (DAPI) was used, but this involved the removal of the spermatozoa membrane, which implicitly led to the loss of spermatozoa viability. Although the use of several dyeing protocols was attempted, quantifying the spermatic DNA together with maintaining viability was achieved only with Hoechst 33342 fluorochrome (H-42) (31).

The non-viable (dead) cells of the spermatozoa population marked with H-42 may be identified by adding propidium iodide (PI), but due to its mutagenic potential, it was replaced by other staining dyes. Currently, the FD-C40 red food dye is used, which is capable of crossing the altered membrane of the spermatozoa cells, masking the fluorescence of the H-42 dye. Dead cells, coloured with FD-C40, are identified and removed during the sorting process (32).

Sample analysis and highlighting of the two sub-populations: flow cytometry is a highly sophisticated system, whose function is to analyse and sort cells based on their physical characteristics (size, cell complexity) or on the fluorescence emitted after they have been marked with fluorochromes.

The basic components of the flow cytometer are the fluidic, optical, and electronic systems (33) (Fig. 1). The fluidic system is represented by sperm cells in suspension in a saline medium with added EDTA and, optionally, 1\% BSA (34). The composition of this medium differs depending on the mammal species in question (35).

Thanks to the vibrations of a piezoelectric crystal, the fluid flow is segmented into drop- 
lets (microvesicles) that contain, in principle, a single sperm cell each and that will form a single-file unicellular internal flow.

The optical system involves the presence of a flow chamber in which sperm cells come into contact with the argon laser-type excitation source and whose dispersion is captured by two photomultipliers (PMT) (fluorescence detectors), located laterally and frontally.

The lateral photomultiplier (situated at a 90-degree angle relative to the laser emitter) identifies the spermatozoa that display a frontal position at the moment of impact with the laser beam, the quantification of DNA being afterwards achieved by the front photomultiplier (situated at a 0 -degree angle relative to the laser).

The impulses of the photomultipliers are received by the electronic system that, with the aid of certain computer software, processes the signals and presents the results in the form of a histogram. On the right side of the histogram, the population which has an intense fluorescence is presented (in the case of sexing, it corresponds to the spermatozoa containing the $\mathrm{X}$ gonosome), while on the left is presented the lower fluores-

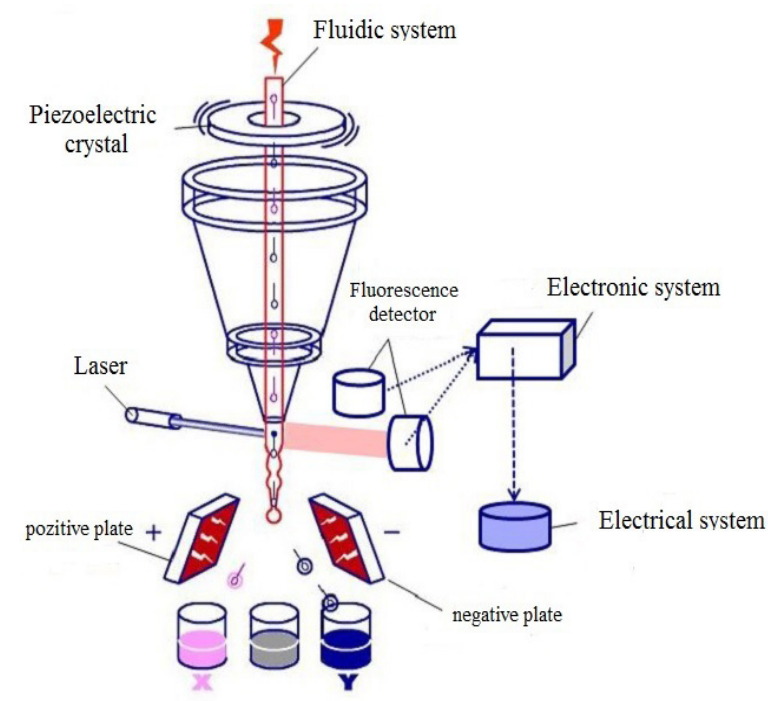

Figure 1. Diagram of flow cytometric sorting (adapted from www.sexingtechnologies.com) cence cell population (which corresponds to the spermatozoa containing the $\mathrm{Y}$ gonosome).

Depending on these aspects, the electronic system sends information to the electrical charging mechanism, which will apply different electric charges to each microvesicle, depending on the degree of fluorescence of the sperm cells.

With the aid of an electrostatic field ( $2000 \mathrm{~V}$ ) produced by the two deflecting plates, the ionized microvesicles are moved in different directions, the spermatozoa cells being therefore separated. The spermatozoa containing the $\mathrm{X}$ gonosome and charged with a positive electric charge are deviated towards the negative plate, while the ones containing the $\mathrm{Y}$ gonosome, charged with a negative electric charge, are deviated towards the positive pole.

The droplets whose content could not be evaluated because the sperm cells are either absent or contain several live or dead spermatozoa (hyperchromic - in the vital coloration due to the loss of cell membrane selectivity), are not electrically charged and will continue their path along the flow, being subsequently eliminated.

The collection of sexed spermatozoa is performed in sterile tubes that have been pre-treated with 1\% BSA and contain "TEST-yolk" medium (34). The tubes are pre-treated with BSA in order to eliminate the electrostatic forces that may occur between the spermatozoa and tube walls. The "TEST-yolk" medium is meant to stabilize the plasmatic membrane of the spermatozoa and to reduce their impact with the collecting tube, considering that the speed at which they are evacuated from the cytometer is $90 \mathrm{~km} / \mathrm{h}(36)$.

\section{Validation of the cytometric method for sexing semen}

It is known that the efficiency and success of artificial insemination performed with sexed semen depends to a large extent on the purity of the sexed spermatozoa. Thus, after the semen has been sexed, its validation can be achieved by several methods: 
1. Reanalysis with the aid of flow cytometry (37). This method involves reanalysing a small quantity of the sexed semen for each sample.

2. Polymerase chain reaction - PCR (38), that, with the aid of a specific primer, amplifies a section of DNA specific to the Y or X chromosome.

3. Fluorescence in situ hybridization - FISH $(4,39)$, through which a specific sequence of the $\mathrm{Y}$ chromosome is highlighted. This technique offers the possibility of validating the sexed semen, both from a quantitative and a qualitative point of view (40).

4. Artificial insemination.

The validation of the sexed semen with the aid of flow cytometer, by reanalysing the already sexed sample, and via molecular biology techniques (PCR and FISH) are the most advantageous methods, despite the fact that they are time-consuming. However, the validation of the method is given by the percentage of offspring whose morphological sex corresponds to that anticipated before the artificial inseminations (37).

\section{Sexing efficiency}

The efficiency of sexing achieved with the aid of the flow cytometer depends to a large extent on the parameters of the sorting system, but also on the quality of semen (41). Consequently, only $30 \%$ of the spermatozoa in one ejaculate are subjected to sexing, while the remaining $70 \%$ are lost in the stages before, during, and after sorting (42).

Leaving aside the small quantitative difference between the DNA of the two spermatozoa categories and the quality of semen, the main obstacle encountered in flow cytometric sexing of spermatozoa is their morphology (i.e. the shape of the head) (43). In most species, the spermatozoa head is flat, and therefore its lateral positioning at the moment of impact with the laser beam undervalues the amount of DNA, unlike the frontal positioning, which leads to an accurate quantification (44).

The sorting speed also depends, among other things, on the pressure to which the fluid column is subjected in order to pass through the cytometer. Even if the normal operating pressure of the cytometer is $12 \mathrm{psi}$, new sorting systems are equipped with "Hypersort" modules, which allow the pressure to be raised up to 100 psi. So far, it was observed that at a pressure of up to 62 psi, the viability of the spermatic cells is not affected (41).

\section{The deterioration degree of spermatozoa sub- jected to the sexing technique}

The entire sorting process includes several critical stages that may affect the qualitative parameters of the spermatozoa. In addition to these stages, careful handling and preparation of semen samples before and after sorting are also essential in maintaining motility, viability, and fertilizing capacity of the sexed spermatic cells (37).

Therefore, during the sorting process, the quality of semen may be diminished by subjecting the sperm cells to:

- Dilution and marking procedures with H-42 (45);

- UV rays (46);

- Flow pressure (47);

- Electrostatic field and electric charge (47).

Also, in order to minimize the damage produced by these potential causes, temperature, osmolality, $\mathrm{pH}$, and sterility of the media and laboratory glassware should be carefully monitored (42).

As early as 1982, Ralph Durand and Peggy Olive stated their suspicions concerning the mutagenic potential of H-42 fluorochrome. However, the results of subsequent studies showed that spermatic DNA, unlike somatic one, has a higher resistance to the action of this fluorochrome, due to its condensed state (48). Thus, so far, no alterations of DNA integrity of $\mathrm{H}-42$ 
marked spermatozoa, no differences concerning cleavage rates and no anomalies regarding the development of blastocysts after IVF with H-42 marked spermatozoa have been reported (49).

According to Bisharah Libbus, the mere exposure of sperm cells to UV rays during sorting is potentially harmful to DNA integrity, but this hypothesis was vehemently challenged by the studies conducted by Sally Catt, that were later confirmed by David Guthrie. According to them, exposure to UV rays for $1 \mu \mathrm{sec}$ during sorting does not pose any mutagenic risk to the spermatozoa (50).

Recently, the influences of flow pressure and electrostatic field on the viability and fertility of spermatozoa have also been investigated. The results show that the optimal cytometer pressure at which the purity, viability, and fertilizing capacity of the spermatozoa are not affected to a great extent is 40-50 psi (47).

Consequently, the losses produced by the cytometric method for sexing semen are inherent, but they are not as great as not to justify its use.

\section{Other methods for sexing spermatozoa}

The scientific literature of the past 70 years contains numerous data on the attempts to separate the two spermatozoa sub-populations. Thus, although physical, biochemical, and immunological differences have been suggested and granting it was attempted to develop several separation techniques based on them, no viable sexed spermatozoa have been obtained in a consistent manner up to date $(17,18)$.

The methods that have been tested to this point, that are not based on the DNA difference between $\mathrm{X}$ and Y-chromosome-bearing spermatozoa are (51):

- $\quad$ Sexing of sperm using antibodies $(52,53)$

- Gradient swim-down procedure (54);

- Free-flow electrophoresis;

- Spermatozoa sexing based on volumetric differences (55);
- Centrifugal countercurrent distribution (56). All of these attempts of obtaining sexed semen have proved to be ineffective due to one of the following drawbacks:

- the distortion or loss of spermatozoa viability;

- the impossibility to extrapolate this technique to mammals;

- inconsistent or unverified results.

Also, due to certain economic interests, a number of reports have emerged concerning the sexed semen and/or offspring whose sex was preselected prior to conception, but, most commonly, these reports proved to be unfounded; proof of this is the fact that no one else has achieved satisfactory results by the same methods. The only method that renders good results and guarantees that viable sexed semen is obtained in relatively satisfactory amounts is the flow cytometric method, also known as Beltsville Technology (57). This method is widely accepted as an efficient method suitable for commercial use. Only Great Britain (Aldford Chester - Cogent Sexed Semen) and a few regions in the United States (Colorado; Navasota, Texas, etc.) hold a trading license for mammals semen sexed via this technology.

Although in recent years a series of major improvements have been achieved regarding sorting speed and the correct orientation of the spermatozoa before the laser beam, the technology is limited in terms of obtaining a dose with the same number of sexed spermatozoa as with unsexed semen.

\section{Ethical issues and legislation}

While mammalian sex selection does not involve any distinctive ethical concerns, unfortunately we cannot say the same in case of humans.

Sex selection in humans, can be separated into two distinct reasons: medical and non-medical. If sex selection for medical reasons is carried out in order to avoid the transmission of $\mathrm{X}$-linked genetic diseases to the next generation, 
sex selection for non-medical reasons is done mostly in order to satisfy parental desires.

Although, sex selection for medical reasons is widely accepted as ethical, the use of sperm sexing technologies for non-medical reason has been the subject of recurrent ethical and intense debate in many countries (58).

Up to now, only 36 countries including Canada, Australia India, China, Turkey, and 25 European countries (59) have laws or policies regarding sex selection. An overview of the legislation shows that none of these allows the use sex selection for non-medical purposes. Moreover, article 14 of the Convention on Human Rights and Biomedicine of 1997 states that "the use of techniques of medically assisted procreation shall not be allowed for the purpose of choosing a future child's sex, except where serious hereditary sex-related disease is to be avoided" (60). Austria and Switzerland go even further and forbid sex selection for any reason. Moreover, in India and China, the law is more restrictive and prenatal ultrasounds diagnosis for sex determination without a medical reason can be prosecuted.

Parental freedom of choice is the most common and strongest argument in favor of non-medical sex selection. People should be able to decide what kind of life they want to live, including having the "right" to make personal decisions regarding with whom, when and how to have children. The government has no right to interfere unless there is objective evidence that the use of sexing sperm technology would affect the resulting child or the society, otherwise violate the right "to freely form families given in the Declaration of Human Rights" (61).

Len Doyal and Sheila McLean finds that using sex selection can ensure a good future of the child, particularly in cultures that have a strong sex preference. For example, a baby girl born into a patriarchal society is more likely to be abandoned, neglected, abused or stigmatized. Likewise can be advantages for women living in oppressive societies. In some Asian and Indian cultures, women who cannot produce male child are blamed, therefore, sex selection can avoid physically and emotionally harmful of those $(62,63)$.

Another argument quoted by those who support non-medical sex selection is that, in this way are avoided many ethical concerns associated with abortion and destruction of embryos for the purpose of sex selection (64).

The primary arguments against allowing preconception sex selection for non-medical reasons are that can lead to sex-ratio imbalance and distortions in birth order, is inherently sexist and violates human dignity, misuse the medical resources for nonmedical purposes, and can induce risks of perpetuation of social injustice and discrimination. Safety is a major ethical concern with any new medical technology. Despite the fact that sperm sorting technology has been used for over 20 years in animals, the long-term medical risks for humans are unknown yet, therefore it is still not FDA-approved for marketing (65).

Also, many critics who argue against non-medical sex selection believe that the possibility to preselect the sex of a child prior to conception is akin to "playing God" by interfering with the natural process of reproduction and what is "natural" ought to be appreciated as part of divine creation. Furthermore the position of the Roman Catholic Church is that the ability to give birth to children is the expression of marital love and should not be isolated from the sexual act $(65,66)$.

In conclusion, the debate over the ethics of sex selection for non-medical reasons is ongoing, in which all of the arguments produced by those who support and those who reject the practice are well persuasive and reasoned. Thus 
far, no promising method is known to offer an alternative to the sperm sexing technology, however, in the years to come, the current method will most likely be improved, or another sexing method will be discovered, reaching a point where safety and long-term medical risks will no longer be a constraint and sexed semen will be more economically viable. Consequently, current legislation, regarding sex selection must be subject to a future revision.

\section{List of abbreviations}

ART - Assisted Reproductive Technology

BSA - Bovine Serum Albumin

DNA - Deoxyribonucleic Acid

EDTA - Ethylene-Diamine-Tetraacetic Acid

FDA - Food and Drug Administration

FISH - Fluorescence In Situ Hybridisation

ICSI - Intra Cellular Sperm Injection

INVO - Intravaginal Culture of Oocytes

IVF - In Vitro Fertilization

PCR - Polymerase Chain Reaction

PMT - photomultiplier tube

UV - Ultraviolet rays

\section{Acknowledgements}

This paper was published under the frame of European Social Found, Human Resources Development Operationl Programme 2007-2013, project no. POSDRU/159/1.5/136893.

\section{References}

1. Garner DL, Seidel Jr GE. History of commercializing sexed semen for cattle. Theriogenology. $2008 \mathrm{Apr}$ 15;69(7):886-95. Epub 2008 Mar 17. DOI: 10.1016/j. theriogenology.2008.01.006

2. Vintilă I. Transferul de embrioni şi biotehnologii asociate. Ed. Orizonturi Universitare Timişoara. 2005;11.

3. Faber DC, Molina JA, Ohlrichs JA, Vander Zwaag DF, Ferré LB, Commercialization of animal biotechnology. Theriogenology. 02/2003, 59(1):125-38.

4. Parrilla I, Vázquez JM, Oliver-Bonet M, Navarro J, Yelamos J, Roca J, et al. Fluorescence in situ hybridization in diluted and flow cytometrically sorted boar spermatozoa using specific DNA direct probes labelled by nick translation. Reproduction. 2003 Sep;126(3):317-25. DOI: $10.1530 /$ rep. 0.1260317

5. Taton R, Armaldez Rbeaujeu., J, Beaujouan G, Bloch R, Bourgey L, et al. Ştiinţa antică şi medievală - de la origini la 1450. Vol.I, Ed. Şţiinţifică Bucureşti.1970; 212-214; 205-14.

6. Windsor DP, Evans G, White IG. Sex predetermination by separation of $\mathrm{X}$ and $\mathrm{Y}$ chromosome-bearing sperm: A review. Reprod Fertil Dev. 1993;5(2):155-71. DOI: 10.1071/RD9930155

7. Seidel GE Jr. Sexing Mammalian Sperm - Where Do We Go from Here? J Reprod Dev. 2012;58(5):505-9. DOI: $10.1262 /$ jrd.2012-077

8. Cuevas I, Llácer J, Ten J, Mendiola J, Bernabeu R. Current situation of sex selection. Situación actual de la selección de sexo. 2002;19(5):337.

9. Spinaci M, Perteghella, S Chlapanidas T, Galeati G, Daniele Vigo, Tamanini C et al. Storage of Sexed Boar Spermatozoa: Limits and Perspectives, Theriogenology. 2015 May 29. pii: S0093-691X(15)00282-4.

10. Xu ZZ. Application of liquid semen technology improves conception rate of sex-sorted semen in lactating dairy cows, Journal of Dairy Science. 2014 Nov 97; 11: 7298-304. DOI: 10.3168/jds.2014-8507

11. Johnson LA. Sex preselection in swine: Altered sex ratios in offspring following surgical insemination of flow sorted X- and Y-bearing sperm. Reprod. Dom. Anim. 1991;26:309-14. DOI: 10.1111/j.1439-0531.1991. tb01546.x

12. Catt SL, O’brien JK, Maxwell WMC, Evans G. Assessment of ram and boar spermatozoa during cell-sorting by flow cytometry. Reprod. Dom. Anim. 1997 Oct 32:251-8.

13. Basil A, Gabriela Mastromonaco, King AK. Recent Advances in Reproductive Biotechnologies in Sheep and Goat. Journal of Veterinary Science \& Technology. 2010 Sept; 1:101.

14. O'brien JK, Steinman KJ, Robeck TR. Application of sperm sorting and associated reproductive technology for wildlife management and conservation. Theriogenology. 2009 Jan 1;71(1):98-107. DOI: 10.1016/j. theriogenology.2008.09.052

15. Seidel GE JR. - Sexing mammalian sperm: intertwining of commerce, technology, and biology. Anim Reprod Sci. 2003, 79 (3-4), p: 145-6. DOI: 10.1016/S03784320(03)00162-3

16. Albert De Vries. The Economics of Sexed Semen in Dairy Heifers and Cows. AN214, of the Animal Science Department, Florida Cooperative Extension Service, Institute of Food and Agricultural Sciences, University of Florida. 2009.

17. Sharpe JC, Evans KM. Advances in flow cytometry for sperm sexing. Theriogenology. 2009 Jan 1;71(1):4-10. 
DOI: 10.1016/j.theriogenology.2008.09.021

18. Gordon IR. Reproductive Technologies in Farm Animals. Ed. CABI Publishing, 2004, 75-79. DOI: 10.1079/9780851998626.0000

19. Espinosa-Cervantes R., Córdova-Izquierdo A. Sexing sperm of domestic animals. Trop Anim Health Prod. 2013 Jan;45(1):1-8. DOI: 10.1007/s11250-012-0215-0

20. Jafar SI, Flint APF. Sex selection in mammals: A review. Theriogenology. 1996;46:191-200. DOI: 10.1016/0093-691X(96)00177-X

21. Johnson LA, Rath D, Vázquez JM, Maxwell WMC, Dobrinsk JR. Preselection of sex of offspring in swine for production: current status of the process and its application. Theriogenology. 2005 Jan 15;63(2):615-24. DOI: 10.1016/j.theriogenology.2004.09.035

22. Cenariu M, Groza I, Pall E, Bogdan L, Morar I, Ciupe S. et al. Sexing of Bovine Embryos Using Polymerase Chain Reaction (PCR) and Fluorescent In Situ Hybridization (FISH). Romanian Biotechnological Letters. 2011;162:6056-61.

23. Lopes RFF, Forell F, Oliveira ATD, Rodrigues JL. Splitting and biopsy for bovine embryo sexing under field conditions. Theriogenology. 2001 Dec 1;56(9):138392. DOI: 10.1016/S0093-691X(01)00641-0

24. Cenariu M, Pall E, Groza IŞ. Ultrasonographic determination of fetal sex in cattle. Bulletin UASMV, Veterinary Medicine. 2012;69:1-2.

25. Larrabee PB, Johnson KL, Pestova E, Lucas M, Wilber K, Leshane ES, et al. Microarray analysis of cellfree fetal DNA in amniotic fluid: a prenatal molecular karyotype. Am J Hum Genet. 2004 Sep; 75(3): 485-91. DOI: $10.1086 / 423288$

26. Van Dilla MA, Gledhill BL, Lake S, Dean PN, Gray JW, Kachel V, et al. Measurement of mammalian sperm deoxyribonucleic acid by flow cytometry- problems and approaches. J Histochem Cytochem. 1977 Jul;25(7):763-73. DOI: 10.1177/25.7.70455

27. Garner DL, Gledhill BL, Pinkel D, Lake S, Stephenson D, Van Dilla M, et al. Quantification of the $\mathrm{X}$ - and Y-chromosome-bearing spermatozoa of domesticanimals by flow cytometry. Biol Reprod. 1983 Mar;28(2):312-21. DOI: 10.1095/biolreprod28.2.312

28. Moruzzi JF. Selecting a mammalian species for the separation of X- and Ychromosome-bearing spermatozoa. J Reprod Fertil. 1979 Nov;57(2):319-23. DOI: $10.1530 /$ jrf.0.0570319

29. Seidel GE Jr., Johnson LA. Sexing mammalian sperm - overview. Theriogenology. December 1999Volume 52, Issue 8, Pages 1267-72. DOI: 10.1016/S0093691X(99)00215-0

30. Welch GR, Johnson LA. Sex preselection: Laboratory validadtion of the sperm sex ratio of flow sorted $\mathrm{X}$ - and Y- sperm by sort reanalysis for DNA. Theriogenology. 1999;52:1343-52 DOI: 10.1016/S0093691X(99)00221-6
31. Johnson LA, Flook JP, Look MV. Flow cytometry of $\mathrm{X}$ - and Y - chromosome-bearing sperm for DNA using an improved preparation method and staining with Hoechst 33342. Gamete Res. 1987; 17, p: 203-12. DOI: 10.1002/mrd.1120170303

32. Schenk JL, Suh TK, Cran D, Gseidel GE Jr. Cryopreservation of flow-sorted bovine spermatozoa. Theriogenology. 1999 Dec;52(8):1375-91. DOI: 10.1016/ S0093-691X(99)00224-1

33. Shapiro HM. Practical flow cytometry. 4th edition. Eds. John Wiley and Sons, Inc., Hoboken, New Jersey. 2003. DOI: $10.1002 / 0471722731$

34. Johnson LA, Flook JP, Hawk HW. Sex preselection in rabbits: live births from X- and Y- sperm separated by DNA and cell sorting. Biol Reprod. 1989 Aug;41(2):199-203. DOI: 10.1095/biolreprod41.2.199

35. Hollinshead FK, Evans G, Evans KM, Catt SL, Maxwell WMC, O'brien JK. Birth of lambs of a pre-determined sex after in vitro production of embryos using frozen-thawed sex-sorted and re-frozen-thawed ram spermatozoa. Reproduction 127, 2004; p: 557-68. DOI: 10.1530/rep.1.00049

36. Johnson LA, Welch GR. Sex pre-selection: high-speed flow cytometric sorting of $\mathrm{X}$ and $\mathrm{Y}$ sperm for maximum efficiency. Theriogenology. 1999 Dec;52(8):1323-41. DOI: 10.1016/S0093-691X(99)00220-4

37. Welch GR, Johnson LA. Sex preselection: Laboratory validadtion of the sperm sex ratio of flow sorted $\mathrm{X}$ - and Y- sperm by sort reanalysis for DNA. Theriogenology. 1999;52:1343-52. DOI: 10.1016/S0093691X(99)00221-6

38. Welch GR, Waldbieser GC, Wall RJ, Johnson LA. Flow cytometric sperm sorting and PCR to confirm separation of X-and Y-bearing bovine sperm. Animal Biotechnology. 1995; 6: 131-9. DOI: $10.1080 / 10495399509525842$

39. Kawarasaki T., Welch GR, Long CR, Yoshida M, Johnson LA. Verification of flow cytometorically-sorted $\mathrm{X}$-and Y-bearing porcine spermatozoa and reanalysis of spermatozoa for DNA content using the fluorescence in situ hybridization (FISH) technique. Theriogenology. 1998 Sep;50(4):625-35. DOI: 10.1016/S0093691X(98)00167-8

40. Piumi F, Vaiman D, Cribiu Ep, Guerin B, Humblot P. Specific cytogenetic labeling of bovine spermatozoa bearing $\mathrm{X}$ or $\mathrm{Y}$ chromosome Using fluorescent in situ hybridization (FISH). Genetic Selection Evolution. 2001; 33: 89-98. DOI: 10.1186/1297-9686-33-1-89

41. Parrilla I, Vazquez JM, Centurion F, Roca J, Gil MA, Lucas X, et al. Effect of high-speed flow sorting on sperm motility pattern of boar sperm. Theriogenology. 2001;55:501(Abstr.).

42. Seidel GE Jr., Garner DL. Current status of sexing mammalian spermatozoa. Reproduction. 2002 Dec;124(6):733-43. DOI: 10.1530/rep.0.1240733 
43. Pinkel D, Lake S, Gledhill BL, Van Dilla MA, Stephenson D, Watchmaker G. High resolution DNA content measurements of mammalian sperm. Theriogenology. 1999 Dec;52(8):1343-52.

44. Rens W, Welch GR, Johnson L. A novel nozzle for more efficient sperm orientation to improve sorting efficiency of $\mathrm{X}$ and $\mathrm{Y}$ chromosome bearing sperm. Cytometry. 1998 Dec 1;33(4):476-8. DOI: 10.1002/ (SICI) 1097-0320(19981201)33:4<476::AID-CYTO12>3.0.CO;2-B

45. Durand RE, Olive PL. Cytotoxicity, mutagenicity and DNA damage by Hoechst 33342. J Histochem Cytochem. 1982 Feb;30(2):111-6. DOI: 10.1177/30.2.7061816

46. Libbus BL, Perreault SD, Johnson LA, Pinkel D. Incidence of chromosome aberration in mammalian sperm stained with Hoechst 33342 and UV-laser irradiated during flow sorting. Mutat Res. 1987 Oct;182(5):26574. DOI: 10.1016/0165-1161(87)90011-2

47. Suh TK, Schenk JL. Pressure during flow sorting of bull sperm affects post-thaw motility characteristics. Theriogenology. 2003;59p: 516. (abstract).

48. Maxwell WMC, Evans G, Hollinshead FK, Bathgate R, De Graaf SP, Eriksson BM et al. Integration of sperm sexing technology into the ART toolbox. Anim Reprod Sci. 2004 Jul;82-83:79-95. DOI: 10.1016/j.anireprosci.2004.04.013

49. Garner DL. Hoechst 33342: the dye that enabled differentiation of living X-and Y-chromosome bearing mammalian sperm. Theriogenology. 2009 Jan 1;71(1):1121. DOI: 10.1016/j.theriogenology.2008.09.023

50. Libbus BL, Perreault SD, Johnson LA, Pinkel D. Incidence of chromosome aberration in mammalian sperm stained with Hoechst 33342 and UV-laser irradiated during flow sorting. Mutat Res. 1987 Oct;182(5):26574. DOI: 10.1016/0165-1161(87)90011-2

51. Amann RP, Seidel GE Jr. Prospects for sexing mammalian sperm. Boulder, CO: Colorado Associated University Pres. 1982.

52. Blecher SR, Howie R, Li S, Detmar J, Blahut L. A new approach to immunological sexing of sperm. Theriogenology. 1999 Dec;52(8):1309-21. DOI: 10.1016/ S0093-691X(99)00219-8

53. Reed K. Cattle Breeding Technologies. Chapter 14 Semen and embryo sexing. 2006:67-9.

54. Ericsson RJ, Ericsson SA. Sex ratios. In Encyclopedia of Reproduction. Vol. 4 Eds E Knobil and JD Neill. Academic Press, London, 1999:431-7.

55. Van Munster E.B. Interferometry in flow to sort unstained X- and Y-chromosome bearing bull spermatozoa. Cytometry. 2002 Mar 1;47(3):192-9. DOI: 10.1002/cyto. 10064

56. Ollero M, Perez-Pe R, Gargallo I, Morlanes S, Osada J, Mui-o-Blanco T, et al. Separation of ram spermatozoa bearing $\mathrm{X}$ and $\mathrm{Y}$ chromosome by centrifugal counter- current distribution in an aqueous two-phase system. J Androl. 2000 Nov-Dec;21(6):921-8.

57. Garner DL, Evans KM, Seidel GE. Sex-Sorting Sperm Using Flow Cytometry/Cell Sorting. Methods Mol Biol. 2013;927:279-95. DOI: 10.1007/978-1-62703038-0 26

58. Strange H. Non-medical sex selection: ethical issues. British Medical Bulletin, 2010; 94:7-20. DOI: 10.1093/ bmb/ldq002

59. Darnovsky M. Countries with laws or policies on sex selection. In: Memo for the April 13 New York City Sex Selection Meeting, 2009.

60. Dondorp W, DeWert G, Pennings G, Shenfield F, Devroey $\mathrm{P}$, Tarlatzis $\mathrm{B}$, Barri $\mathrm{P}$, Diedrich K. SHRE Task Force on Ethics and Law 20: Sex selection for non medical reasons. Hum Reprod. 2013;28(6):1448-54. DOI: $10.1093 /$ humrep/det109

61. Dawson K, Trounson A. Ethics of sex selection for family balancing. Why balance families? Hum Reprod. 1996 Dec;11(12):2577-8. DOI: 10.1093/oxfordjournals.humrep.a019171

62. Doyal, L., McLean, S. Choosing children: intergenerational justice? Reprod Biomed Online. 2005 Mar;10 Suppl 1:119-24. DOI: 10.1016/S14726483(10)62219-5

63. Dai J. Preconception sex selection: the perspective of a person of the undesired gender. Am J Bioeth. 2001 Winter;1(1):37-8. DOI: 10.1162/152651601750079032

64. Puri S, Nachtigall RD. The ethics of sex selection: A comparison of the attitudes and experiences of primary care physicians and physician providers of clinical sex-selection services. Fertil Steril. 2010 May 1;93(7):2107-14. DOI: 10.1016/j.fertnstert.2009.02.053

65. Kalfoglou AL, Kammersell M, Philpott S, Dahl E. Ethical arguments for and against sperm sorting for non-267 medical sex selection: a review. Reprod Biomed Online 2013;26:231-9. DOI: 10.1016/j.rbmo.2012.11.007

66. Liao SM. The ethics of using genetic engineering for sex selection. Med Ethics 2005;31:116-118. DOI: 10.1136/jme.2003.005983 